\title{
Role of sand lizards in the ecology of Lyme and other tick-borne diseases in the Netherlands
}

\author{
Ellen Tijsse-Klasen 1, Manoj Fonville1, Johan HJ Reimerink², Annemarieke Spitzen - van der Sluijs³ and Hein Sprong*1
}

\begin{abstract}
Background: Lizards are considered zooprophylactic for almost all Borrelia burgdorferi species, and act as dilution hosts in parts of North America. Whether European lizards significantly reduce the ability of B. burgdorferi to maintain itself in enzootic cycles, and consequently decrease the infection rate of Ixodes ricinus ticks for B. burgdorferi and other tickborne pathogens in Western Europe is not clear.

Results: Ticks were collected from sand lizards, their habitat (heath) and from the adjacent forest. DNA of tick-borne pathogens was detected by PCR followed by reverse line blotting. Tick densities were measured at all four locations by blanket dragging. Nymphs and adult ticks collected from lizards had a significantly lower (1.4\%) prevalence of $B$. burgdorferi sensu lato, compared to questing ticks in heath (24\%) or forest (19\%). The prevalence of Rickettsia helvetica was significantly higher in ticks from lizards (19\%) than those from woodland (10\%) whereas neither was significantly different from the prevalence in ticks from heather (15\%). The prevalence of Anaplasma and Ehrlichia spp in heather (12\%) and forest (14\%) were comparable, but significantly lower in ticks from sand lizards (5.4\%). The prevalence of Babesia spp in ticks varied between 0 and 5.3\%. Tick load of lizards ranged from 1 - 16. Tick densities were $\sim 5$-fold lower in the heather areas than in woodlands at all four sites.
\end{abstract}

Conclusions: Despite their apparent low reservoir competence, the presence of sand lizards had insignificant impact on the B. burgdorferi s.l. infection rate of questing ticks. In contrast, sand lizards might act as reservoir hosts for $R$. helvetica. Remarkably, the public health risk from tick-borne diseases is approximately five times lower in heather than in woodland, due to the low tick densities in heather.

\section{Background}

Several tick-borne diseases are emerging in Europe as shown by the example of a dramatic increase of Lyme disease cases over the last decade [1,2]. Furthermore, an increasing prevalence and number of Rickettsia species have been identified as causative agents of tick-borne rickettsioses in Europe [3,4]. The underlying causes for the spread of zoonotic diseases such as these include human behaviour, mankind's irrepressible impact on the environment and a changing climate [5-8]. They are affecting the highly dynamic and only partially understood interactions between infectious agents, their hosts, vectors and the environment. The predominant vector of

\footnotetext{
*Correspondence: A.Spitzen@ravon.nl, Hein.Sprong@rivm.nl

${ }^{3}$ Reptile, Amphibian and Fish Conservation Netherlands (RAVON), PO Box

1413, 6501 BK Nijmegen, the Netherlands

${ }^{1}$ Laboratory for Zoonoses and Environmental Microbiology, National Institute for Public Health and Environment (RIVM), Antonie van Leeuwenhoeklaan 9, PO Box 1, Bilthoven, the Netherlands

Full list of author information is available at the end of the article
}

B. burgdorferi in Europe is Ixodes ricinus. This tick species feeds on a wide variety of warm- and cold-blooded vertebrates, including humans. Some of these tick hosts are incompetent hosts for various $B$. burgdorferi genospecies. The hypothesized origin of such specific associations is that different groups of vertebrates exhibit distinct types of innate immunity, which may either tolerate or destroy certain B. burgdorferi genospecies [9-11]. Incompetent hosts, in contrast to competent ones, fail to acquire, maintain or transmit a parasitic microorganism and therefore do not contribute to or even limit the spread of tick borne pathogens.

At least eight lizard species, including Lacerta agilis (sand lizards), have been identified as incompetent hosts for all B. burgdorferi genospecies, except B. burgdorferi lusitaniae [12-21]. The blood of some lizard species was found to possess borreliacidal properties and therefore these lizards are even able to clear the bacteria from previously infected ticks [22-24]. The presence of such an 
incompetent host might reduce the ability of $B$. burgdorferi to maintain itself in an enzootic cycle $[25,26]$ and might act zooprophylactic by reducing the prevalence of B. burgdorferi in ticks and diverting tick bites away from competent hosts [15,27]. This dilution effect will only apply if the vector has multiple hosts and the incompetent host is an important feeding source for the vector $[26,28]$. Lizards have been shown to contribute to the dilution effect in several areas in the United States of America $[29,30]$. In the Netherlands lizards occur on heath, the coastal dunes and in open woodlands on the higher sandy soils in the eastern, southern and central part of the country. In some of these areas lizard populations are dense with up to 100 individuals per hectare $[31,32]$.

Various studies in the Netherlands and other European countries evaluated the prevalence of I. ricinus on sand lizards. The mean number of ticks per lizard varied from 0.2 to 23 and maximal numbers of ranged from 42 to 61 in different study areas [33-35]. These studies indicate that in certain habitats lizards are relevant hosts for $I$. ricinus. Small rodents, probably the most relevant $B$. burgdorferi reservoir in the Netherlands, serve mainly as hosts for the larval stage of I. ricinus while sand lizards feed often a much higher proportion of nymphs (larvae/ nymph ratio 1.6 compared to 14 - 39 for small rodents) $[16,36]$. Due to the low larvae/nymph ratio on sand lizards their zooprophylactic effect should theoretically be high. Previous studies suggest that sand lizards are incompetent hosts for most B. burgdorferi s.l species except $B$. burgdorferi lusitaniae $[15,20]$, but their effects on $B$. burgdorferi prevalence in questing ticks have not been investigated.

Recently, Rickettsia helvetica was identified the most prevalent potentially pathogenic Rickettsia in Dutch ticks $[37,38]$. As $R$. helvetica can be transmitted vertically from one tick generation to the next by trans-stadial and transovarial transmission it is less dependent on the presence of competent vertebrate hosts and therefore a dilution effect is less likely to occur [37,39]. Nevertheless, large variations in infection rates and an increased prevalence in adult ticks have been observed and indicate that vertebrate hosts contribute to the maintenance of Rickettsia in tick populations $[37,40]$. A few vertebrates have been identified as competent hosts for R. helvetica whereas no incompetent hosts have been found so far $[37,41]$. To date, the pathogenic potential of $R$. helvetica is unclear, but infection with $R$. helvetica has been suspected in acute perimyocarditis, unexplained febrile illness and sarcoidosis [42-49].

Ehrlichia and Anaplasma species are intracellular bacteria that can be transmitted by tick bites. The causative agent for human monocytic anaplasmosis is Ehrlichia chaffeensis [50] and an other medically important member of this group is the human granulocytic anaplasmosis agent (HGA), Anaplasma phagocytophilum [51]. A recent study on Anaplasma and Ehrlichia in Dutch ticks found mainly Ehrlichia schotti variant, which is of unknown pathogenicity [52].

Various Babesia species are known to cause disease in humans, cattle and companion animals and are usually transmitted by tick bites. In Europe, Babesia divergens is thought to be the most important species to cause human disease but other species have recently been identified as human pathogens in Europe as well [53]. The protozoa invade red blood cells and can cause severe disease. The increase of immuno-compromised and splenectomized individuals in modern society has also led to an increase in the number and intensity of diagnosed babesioses $[53,54]$. B. microti and a Babesia EU1 (proposed name Babesia venatorum) have been repeatedly been identified in ticks in the Netherlands [55].

Here, we investigated the role of sand lizards in the ecology of tick-borne pathogens, in particular B. burgdorferi s.l. and $R$. helvetica. A non-invasive field study was set up which includes the collection of ticks from lizards and vegetation in their habitats as well as from vegetation in geographically nearby control areas that did not serve as a lizard habitat. Tick and lizard densities as well as the infection rate of the different habitats were determined and compared.

\section{Materials and methods \\ Collection of ticks and lizards}

Field sampling was conducted between May and October in the years 2007 till 2009. Ticks were collected by flagging vegetation as described by Wielinga et al. in four different geographical upcountry areas (Heumensoord, Bergherbos, Leusderheide, Hullenberg) from both heathland (sand lizard habitat) and forest areas (unsuitable lizard habitat), which were directly adjacent to each other [52]. Sand lizards do not occur in dense forest therefore this type of landscape was categorized as unsuitable habitat whereas heathland, their main habitat, was categorized as suitable. No lizards were encountered during the flagging in the forest areas. Lizards were captured by hand and ticks attached to the lizards were counted and collected. Sex of the lizard was determined on site and the location of the attached ticks noted. The lizards were returned to their site of capture immediately after examination and tick removal. Ticks were immersed in 70\% ethanol and stored at $-20^{\circ} \mathrm{C}$ upon arrival in the laboratory. Based on morphological criteria tick species and stage were determined. 


\section{Measuring tick and lizard densities}

Tick densities were estimated at the different sampling locations by dragging a $100 \mathrm{~cm}$ wide flannel cloth over a distance of $100 \mathrm{~m}$ with checking for ticks every $25 \mathrm{~m}$. Nymphs and adult ticks were collected from the cloth and counted. This was repeated four times at each location and the counts were averaged. Tick densities of adjacent heath and forest areas were determined on the same day and under equal weather conditions. Lizard densities were estimated by expert judgment, based on the yearly monitoring data from all study areas [56].

\section{Nucleic acid extraction, polymerase chain reactions and reverse line blotting}

Total DNA was extracted from the ticks by alkaline lysis as described elsewhere [57]. DNA extracts were stored at $-20^{\circ} \mathrm{C}$. The presence of the DNA of different tick-borne pathogenic species (Rickettsia spp., B. burgdorferi s.l., Ehrlichia/Anaplasma spp. and Babesia spp.) was determined by polymerase chain reaction (PCR) followed by reverse line blotting (RLB) as described before $[52,57,58]$. The probes that were used for RLB analysis of the PCR products can be found in Table 1 .

\section{B. burgdorferi s.I}

The 23S-5S intergenic spacer region of B. burgdorferi s. 1 . was amplified by PCR with the HotStarTaq master mix (Qiagen, Venlo, The Netherlands) with the following conditions: $15 \mathrm{~min} 94^{\circ} \mathrm{C}$, then cycles of $20 \mathrm{~s} 94^{\circ} \mathrm{C}, 30 \mathrm{~s} 70^{\circ} \mathrm{C}$, $30 \mathrm{~s} 72^{\circ} \mathrm{C}$ lowering the annealing temperature $1^{\circ} \mathrm{C}$ each cycle till reaching $60^{\circ} \mathrm{C}$, then 40 cycles at this annealing temperature and ending by $7 \min 72^{\circ} \mathrm{C}$.

\section{Rickettsia spp}

The 16S rRNA gene of Rickettsia species was amplified by PCR with the HotStarTaq master mix with the following conditions: $15 \min 94^{\circ} \mathrm{C}$, then cycles of $20 \mathrm{~s} 94^{\circ} \mathrm{C}, 30 \mathrm{~s}$ $72^{\circ} \mathrm{C}, 30 \mathrm{~s} 72^{\circ} \mathrm{C}$ lowering the annealing temperature $1^{\circ} \mathrm{C}$ each cycle till reaching $62^{\circ} \mathrm{C}$, then 40 cycles at this annealing temperature followed by a final elongation step for $7 \mathrm{~min}$ at $72^{\circ} \mathrm{C}$. For this study we designed two new RLB probes that are able to hybridize to DNA of most Rickettsia species except for $R$. helvetica and closely related species. These probes were designed with the purpose to establish the occurrences of possible multiple infections of ticks with Rickettsia species. Newly designed probes were tested with a series of samples and positive controls before incorporating them in the assay (not shown). In a second PCR (forward primer: AGAGTTTGATCCTGGCTCAGAAC, reverse primer: CCTACGGCTACCTTGTTACGACTT) on a small subset of samples a longer fragment of the 16S rRNA gene was amplified and sequenced to be able to compare the sequences in more detail.

\section{Other tick-borne pathogens}

The 16S rRNA gene of Ehrlichia and Anaplasma species was amplified by PCR with the HotStarTaq master mix with the following conditions: $15 \mathrm{~min} 94^{\circ} \mathrm{C}$, then cycles of $20 \mathrm{~s} 94^{\circ} \mathrm{C}, 30 \mathrm{~s} 65^{\circ} \mathrm{C}, 30 \mathrm{~s} 72^{\circ} \mathrm{C}$ lowering the annealing temperature $1^{\circ} \mathrm{C}$ each cycle till reaching $55^{\circ} \mathrm{C}$, then 20 cycles at this annealing temperature and an additional 20 cycles with an annealing temperature of $63^{\circ} \mathrm{C}$ followed by a final elongation step for $7 \mathrm{~min}$ at $72^{\circ} \mathrm{C}$.

The 18S rRNA gene of Babesia was amplified by PCR using a reaction mix containing $1 \times$ buffer, $1.75 \mathrm{mM}$ magnesium chloride, $200 \mu \mathrm{M}$ dNTPs, $0.25 \mu \mathrm{M}$ of each primer and Taq polymerase. The PCR reaction was run under following conditions: $10 \mathrm{~min} 94^{\circ} \mathrm{C}$, then cycles of $20 \mathrm{~s}$ $94^{\circ} \mathrm{C}, 30 \mathrm{~s} 67^{\circ} \mathrm{C}, 30 \mathrm{~s} 72^{\circ} \mathrm{C}$ lowering the annealing temperature $1^{\circ} \mathrm{C}$ each cycle till reaching $57^{\circ} \mathrm{C}$, then 40 cycles at this annealing temperature followed by a final elongation step for $7 \mathrm{~min}$ at $72^{\circ} \mathrm{C}$.

To minimize cross contamination and false-positive results, positive and negative controls were included in each batch tested by the PCR and RLB assays. Furthermore DNA extraction, PCR mix preparation, sample addition, and PCR analysis were performed in assigned separate labs. PCR products of some samples were sequenced by dideoxy-dye termination sequencing of both strands, and compared with sequences in Genbank http://www.ncbi.nlm.nih.gov/ using BLAST. The sequences were aligned and analyzed using BioNumerics 5.1 (Applied Maths, Kortrijk, Belgium).

\section{Statistical analysis}

Data were analyzed using tools provided by OpenEpi [59] and Quantitative Parasitology 3.0 (QP3.0) [60]. Confidence intervals (95\%) and two-tailed p-values were calculated using Fisher's exact test.

\section{Results}

In total 713 ticks were collected: 491 from vegetation and 222 from lizards (Table 2). Ticks collected from lizards were mainly larvae and nymphs with larvae/nymph ratios varying from 0.17 to 2.7 (Table 3 ). As larvae were usually omitted during flagging, ticks collected from vegetation were mainly nymphs and only a few adults. Large variations in tick densities (nymphs+ adults) between the locations and between the two vegetation types were observed (Table 4). The number of questing nymphs and adults was significantly lower in heather vegetation than in adjacent forest (bootstrap analysis with 5000 repetitions conjointly for 4 locations: $\mathrm{p}<0.0001)$. Ninety-two individual sand lizards (51 males, 39 females and 2 subadults) were captured in the study areas which had a total of 290 attached ticks. The number of ticks on individual lizards ranged from 1 - 16 individuals (Table 5), with an 
Table 1: Primers and probes used in this study for PCR and RLB. Reverse primers were labeled with Biotintetraethyleneglycol. All probes were 5'-amino-labeled.

\begin{tabular}{|c|c|c|c|c|c|}
\hline Name & Sequence (5' - 3') & Type & Target & Species & Reference \\
\hline $5 \mathrm{~S}$ borSeq & GAGTTCGCGGGAGAGTAGGTTATTGCC(1) & Primer & $23 S-5 S$ IGS & B. burgdorferi sensu lato & {$[52]$} \\
\hline $23 \mathrm{~S}$ borSeq & TCAGGGTACTTAGATGGTTCACTTCC & Primer & $23 S-5 S$ IGS & B. burgdorferi sensu lato & {$[52]$} \\
\hline A-borsl1 & CTTTGACCATATITTTATCTTCCA & Probe & $23 S-5 S$ IGS & B. burgdorferi sensu lato & {$[68]$} \\
\hline A-borsl2 & СТTCCATCTCTATTIAGCCAATTT & Probe & $23 S-5 S$ IGS & B. burgdorferi sensu lato & {$[52]$} \\
\hline A-borsl3 & TATTITATСТTССАТСТСТАТTाT & Probe & $23 S-5 S I G S$ & B. burgdorferi sensu lato & {$[52]$} \\
\hline B31-A-s. stricto & AACACCAATATTTAAAAAACATAA & Probe & $23 S-5 S$ IGS & B. burgdorferi sensu stricto & {$[68]$} \\
\hline Ga2-garinii & AACATGAACATCTAAAAACATAAA & Probe & $23 S-5 S$ IGS & B. garinii & {$[68]$} \\
\hline Vs46IN2afzelii & AACATTTAAAAAATAAATTCAAGG & Probe & $23 S-5 S$ IGS & B. afzelii & {$[68]$} \\
\hline Vsll62 val & $\begin{array}{l}\text { CATTAAAAAAATATAAAAAATAAATTTAA } \\
\text { GG }\end{array}$ & Probe & $23 S-5 S$ IGS & B. valaisiana & [68] \\
\hline A-Ruski & GAATAAAACATTCAAATAATATAAAC & Probe & $23 S-5 S$ IGS & B. afzelii (variant ruski) & [69] \\
\hline A-LusiP & CAAAAAAATGAACATTTAAAAAC & Probe & $23 S-5 S$ IGS & B. lusitaniae & {$[58]$} \\
\hline B-GA1b & $\begin{array}{l}\text { CGGGATCCCGAGTTTGCCGGGACTTCTTC } \\
\mathrm{T}^{(1)}\end{array}$ & Primer & 16SrRNA & Ehrlichia/Anaplasma & [57] \\
\hline $16 \mathrm{~S} 8 \mathrm{Fe}$ & GGAATTCAGAGTTGGATCMTGGYTCAG & Primer & 16SrRNA & Eubacteria & {$[70]$} \\
\hline Ehr-all & TTATCGCTATTAGATGAGCC & Probe & 16SrRNA & Anaplasma genus & {$[57]$} \\
\hline A-HGE & GCTATAAAGAATAGTTAGTGG & Probe & $16 S r R N A$ & HGE agent & {$[57]$} \\
\hline A-Eqph & TTGCTATAAAGAATAATTAGTGG & Probe & 16SrRNA & A. phagocytophilum & {$[57]$} \\
\hline A-dHGE & GCTATGAAGAATAGTTAGTG & Probe & 16SrRNA & HGE agent (variant) & {$[57]$} \\
\hline A-dPh & TTGCTATGAAGAATAATTAGT & Probe & $16 S r R N A$ & A. phagocytophilum variant & {$[52]$} \\
\hline A-E. Schot & GCTGTAGTITACTATGGGTA & Probe & 16SrRNA & E. schotti (variant) & {$[57]$} \\
\hline A-murisT & AGCTATAGGTTTGCTATTAGT & Probe & $16 S r R N A$ & E. muris T variant & [69] \\
\hline A-Chaff & ACCTTTTGGTTATAAATAATTGTTA & Probe & 16SrRNA & E. chaffeensis & {$[57]$} \\
\hline A-can & TCTGGCTATAGGAAATTGTTA & Probe & 16SrRNA & E. canis & {$[57]$} \\
\hline A-Wolbach & CTACCAAGGCAATGATCTA & Probe & 16SrRNA & Wolbachia & {$[52]$} \\
\hline Rick-16S rev & ACTCACTCGGTATTGCTGGA(1) & Primer & 16SrRNA & Rickettsia genus & {$[58]$} \\
\hline Rick-16S for & AACGCTATCGGTATGCTTAACA & Primer & 16SrRNA & Rickettsia genus & {$[58]$} \\
\hline A-Rickall & TITAGAAATAAAAGCTAATACCG & Probe & 16SrRNA & Rickettsia genus & {$[58]$} \\
\hline A-Rhelv2 & GCTAATACCATATATTCTCTATG & Probe & $16 S r R N A$ & R. helvetica & {$[58]$} \\
\hline A-Rconor & CTTGCTCCAGTTAGTTAGT & Probe & 16SrRNA & R. conorii & {$[58]$} \\
\hline A-16SRickIRS & GTATATTCTCTACGGAAAAAA & Probe & 16SrRNA & Rickettsia IRS3 & {$[58]$} \\
\hline A-RProwaz & CGGATTAACTAGAGCTCGCT & Probe & 16SrRNA & Rickettsia prowazekii & This study \\
\hline A-RTyphi & CGGATTAATTAGAGCTTGCT & Probe & 16SrRNA & Rickettsia typhi & This study \\
\hline A-NonHelv A & AATACCGTATATTCTCTACGGA & Probe & 16SrRNA & Non-Rickettsia helvetica & This study \\
\hline A-NonHelv B & AATACCGTATATTCTCTGCGGA & Probe & 16SrRNA & Non-Rickettsia helvetica & This study \\
\hline BATH-Rn & TAAGAATTCACCTCTGACAGTTA(1) & Primer & 18SrRNA & Babesia genus & {$[55]$} \\
\hline BATH-Fn & ACACAGGGAGGTAGTGACAAG & Primer & 18SrRNA & Babesia genus & {$[55]$} \\
\hline Catch all 2 & GTAATGGTTAATAGGARCRGTT & Probe & 18SrRNA & Babesia genus & {$[55]$} \\
\hline Ba-div & GTTAATATTGACTAATGTCGAG & Probe & 18SrRNA & B. divergens & {$[71]$} \\
\hline Ba-mic 1 & CCGAACGTTATTITATTGATT & Probe & 18SrRNA & B. microti & This study \\
\hline Ba-mot & GCTTGCTIITTTGTTACTTTG & Probe & 18SrRNA & B. motasi & {$[55]$} \\
\hline
\end{tabular}


Table 1: Primers and probes used in this study for PCR and RLB. Reverse primers were labeled with Biotintetraethyleneglycol. All probes were 5'-amino-labeled. (Continued)

\begin{tabular}{llllll}
\hline Ba-mic 2 & GRCTTGGCATCWTCTGGA & Probe & 18SrRNA & B.microti & {$[55]$} \\
Ba-EU1 & CTGCGTTATCGAGTTATTG & Probe & 18SrRNA & B.EU1 & This study \\
\hline
\end{tabular}

(1) Reverse primer 5'-labeled with biotine tetraethyleneglycol

average of 3.3 (CI: 2.7 - 4.0) ticks per lizard. The tick load of males was not significantly different from females (bootstrap t-test with 2000 replications; $\mathrm{p}=0.6$ ). Almost all ticks (265 of 290) were found in the armpits of the forelimbs (Table 6), which was in agreement witch earlier studies [33].

\section{B. burgdorferi s.l}

PCR and RLB showed that B. burgdorferi s.l., Rickettsia and Ehrlichia/Anaplasma species were present in ticks collected from all geographical areas (Table 2). The overall infection rate of all collected ticks was 15 percent (CI: $12 \%-18 \%)$ for B. burgdorferi s.l. Notably, none of the ticks collected from lizards from Heumensoord, Bergherbos and Leusderheide were positive for B. burgdorferi s.l. while infection rates of ticks collected from vegetation in these areas varied from $8 \%$ (Heumensoord, heather; CI: $1.6 \%-21 \%$ ) to $26 \%$ (Leusderheide, woodland; CI: $17 \%$ $38 \%)$. From the 58 ticks collected from lizards from the Hullenberg area, only three were positive for B. burgdorferi genospecies (one B. burgdorferi sensu stricto, two $B$. burgdorferi afzelii) while ticks from forest (woodland) and heather in this area had significantly higher infection rates of $21 \%(\mathrm{CI}: 14 \%-30 \%$; $\mathrm{p}=0.008)$ and $44 \%(\mathrm{CI}: 31 \%$ $58 \% ; \mathrm{p}=0.000001)$, respectively. The only B. burgdorferi species associated with lizards, B. lusitaniae, was not detected in any tick tested during this study. The infection rates were not significantly different between questing ticks in forest (woodland) and heathers areas. The genospecies of $B$. burgdorferi isolates were determined by RLB. B. afzelii was the most prevalent B. burgdorferi species in ticks from all areas and vegetation types. Other species identified were $B$. burgdorferi garinii in a total of 5 ticks, all collected from woodlands, B. burgdorferi sensu stricto $(\mathrm{n}=6)$ and B. burgdorferi valaisiana $(\mathrm{n}=2$, both from woodland). Eight samples hybridized with the catch-all probe for B. burgdorferi s.l. but could not be identified to the species level by RLB. The 5S-23S rRNA intergenic spacer regions of these samples were later sequenced and identified as B. afzelii (not shown).

\section{Rickettsia spp}

Rickettsia spp. were found in all four investigated areas in ticks collected from heather, woodland and lizards with high spatial variations and infection rates ranging from 5 33\% (Table 2). Comparing forest (woodland) areas with heather areas there is an apparent but not statistically sig- nificant trend that ticks from heather have higher infection rates $(\mathrm{p}=0.06)$ (Figure 1$)$. Furthermore, the infection rates of ticks collected from lizards were significantly higher $(p=0.03)$ when the data of all locations were analyzed conjointly (Figure 1). Eighty-one percent of the detected Rickettsia spp. were identified as $R$. helvetica by RLB. The remaining positive samples hybridized with a Rickettsia typhi probe $(\mathrm{n}=3)$ or the catch-all probe for Rickettsia spp. only. The 16S rRNA sequences of these samples were later identified as Rickettsia bellii-like sequences with 1 to 6 of about 356 nucleotides difference to $R$. bellii (Genbank accession No U11014). No infections with more than one Rickettsia species were found.

\section{Other tick-borne pathogens}

Ehrlichia/Anaplasma spp. were found with infection rates between 0 and $26 \%$ with highly variable infection rates between the three areas and within the different tick groups. From all ticks collected from Heumensoord only one $(0.8 \%)$ was positive for Ehrlichia/Anaplasma while in Hullenberg $15 \%$ were positive. All but nine positive ticks were identified as Ehrlichia schotti. Two were identified by RLB as Anaplasma phagocytophilum. The remaining seven samples could not be determined to the species level. Ehrlichia/Anaplasma prevalence was significantly higher in ticks collected from forest $(p=0.002)$ and heather $(p=0.02)$ than in ticks collected from lizards (Figure 1). The prevalence of ticks from forest and heather was not significantly different $(\mathrm{p}=0.6)$. No Babesia spp. were detected in ticks from Leusderheide or Heumensoord. In Hullenberg a total of 10 ticks were positive while in Bergherbos three ticks sampled from lizards and one from the forest area were positive (Table 2).

\section{Discussion}

Previous reports from North America and Europe indicated that lizards are incompetent hosts for most B. burgdorferi species and could therefore lead to dilution effects within tick populations $[16,21,61]$. In these studies, however, the B. burgdorferi prevalence in the questing tick population was often not addressed and control areas without lizards were not included [62]. The impact of lizards on other tick-borne pathogens had not been addressed either. Here, we included ticks from different heather and control areas and by tested for various pathogens. Heather with the same characteristics as the study area but without lizards would have been the most ideal 
Table 2: Numbers of ticks collected from lizards and vegetation in the four study areas which were tested positive for tick-borne pathogens by PCR-RLB.

\begin{tabular}{|c|c|c|c|c|c|c|c|c|c|c|c|c|}
\hline \multirow{2}{*}{$\begin{array}{l}\text { Location } \\
\text { RLB positive ticks } \\
\text { number (\%) }\end{array}$} & \multicolumn{3}{|c|}{ Heumensoord } & \multicolumn{3}{|c|}{ Bergherbos } & \multicolumn{3}{|c|}{ Leusderheide } & \multicolumn{3}{|c|}{ Hullenberg } \\
\hline & $\begin{array}{l}\text { Lizards } \\
(n=48)\end{array}$ & $\begin{array}{l}\text { Heather } \\
(n=39)\end{array}$ & $\begin{array}{l}\text { Forest } \\
(n=50)\end{array}$ & $\begin{array}{l}\text { Lizards } \\
(n=61)\end{array}$ & $\begin{array}{l}\text { Heather } \\
(n=40)\end{array}$ & $\begin{array}{l}\text { Forest } \\
(n=41)\end{array}$ & $\begin{array}{l}\text { Lizards } \\
(n=55)\end{array}$ & $\begin{array}{l}\text { Heather } \\
(n=70)\end{array}$ & $\begin{array}{l}\text { Forest } \\
(n=76)\end{array}$ & $\begin{array}{l}\text { Lizards } \\
(n=58)\end{array}$ & $\begin{array}{l}\text { Heather } \\
(n=57)\end{array}$ & $\begin{array}{l}\text { Forest } \\
(n=118)\end{array}$ \\
\hline B. burgdorferi & $0(0)$ & $3(8)$ & $5(10)$ & $0(0)$ & $7(18)$ & $4(10)$ & $0(0)$ & $14(20)$ & $20(26)$ & $3(5)$ & $25(44)$ & $25(21)$ \\
\hline B. b. sensu stricto & 0 & 1 & 1 & 0 & 0 & 1 & 0 & 1 & 0 & 1 & 0 & 1 \\
\hline B. garinii & 0 & 0 & 2 & 0 & 0 & 0 & 0 & 0 & 2 & 0 & 0 & 1 \\
\hline B. afzelii & 0 & 2 & 2 & 0 & 7 & 2 & 0 & 13 & 18 & 2 & 25 & 23 \\
\hline B. valaisiana & 0 & 0 & 0 & 0 & 0 & 1 & 0 & 0 & 1 & 0 & 0 & 0 \\
\hline Ehrlichia/Anaplasma & $0(0)$ & $0(0)$ & $1(2)$ & $11(18)$ & $4(10)$ & $3(7)$ & $1(2)$ & $6(9)$ & $16(21)$ & $0(0)$ & $15(26)$ & $20(17)$ \\
\hline E. schotti & 0 & 0 & 0 & 10 & 4 & 3 & 1 & 6 & 14 & 0 & 13 & 17 \\
\hline $\begin{array}{l}\text { A. } \\
\text { phagocytophilum }\end{array}$ & 0 & 0 & 0 & 0 & 0 & 0 & 0 & 0 & 0 & 0 & 0 & 2 \\
\hline Unspeciated & 0 & 0 & 1 & 1 & 0 & 0 & 0 & 0 & 2 & 0 & 2 & 1 \\
\hline Rickettsia & $16(33)$ & $11(28)$ & $13(26)$ & $9(15)$ & $3(8)$ & $2(5)$ & $7(13)$ & $9(13)$ & $6(8)$ & $10(17)$ & $10(18)$ & $7(5,9)$ \\
\hline R. helvetica & 16 & 7 & 12 & 8 & 1 & 2 & 1 & 7 & 5 & 9 & 10 & 5 \\
\hline R. typhi & 0 & 0 & 0 & 0 & 1 & 0 & 2 & 0 & 0 & 0 & 0 & 0 \\
\hline Unspeciated & 0 & 4 & 1 & 1 & 1 & 0 & 4 & 2 & 1 & 1 & 0 & 2 \\
\hline Babesia & $0(0)$ & $0(0)$ & $0(0)$ & $3(5)$ & $0(0)$ & $1(2)$ & $0(0)$ & $0(0)$ & $0(0)$ & $2(3,4)$ & $3(5,3)$ & $5(4,2)$ \\
\hline B. microti & 0 & 0 & 0 & 2 & 0 & 0 & 0 & 0 & 0 & 1 & 3 & 3 \\
\hline B.EU1 & 0 & 0 & 0 & 1 & 0 & 0 & 0 & 0 & 0 & 1 & 0 & 2 \\
\hline Unspeciated & 0 & 0 & 0 & 0 & 0 & 1 & 0 & 0 & 0 & 0 & 0 & 0 \\
\hline
\end{tabular}

Percentage of positives are in brackets. 
Table 3: Tick stages collected from vegetation and lizards.

\begin{tabular}{|c|c|c|c|c|c|c|c|c|c|c|c|c|}
\hline & \multicolumn{2}{|c|}{ Heumensoord } & \multirow[b]{2}{*}{ Forest } & \multicolumn{2}{|c|}{ Bergherbos } & \multirow[b]{2}{*}{ Forest } & \multicolumn{2}{|c|}{ Leusderheide } & \multirow[b]{2}{*}{ Forest } & \multicolumn{2}{|c|}{ Hullenberg } & \multirow[b]{2}{*}{ Forest } \\
\hline & Lizards & Heather & & Lizards & Heather & & Lizards & Heather & & Lizards & Heather & \\
\hline L & 21 & 0 & 0 & 8 & 2 & 2 & 38 & 17 & 0 & 11 & 0 & 0 \\
\hline $\mathrm{N}$ & 21 & 31 & 46 & 48 & 25 & 34 & 14 & 46 & 76 & 46 & 56 & 112 \\
\hline $\mathrm{F}$ & 1 & 7 & 1 & 0 & 2 & 2 & 0 & 1 & 0 & 0 & 0 & 0 \\
\hline M & 0 & 1 & 3 & 0 & 11 & 0 & 0 & 1 & 0 & 0 & 0 & 5 \\
\hline U & 5 & 0 & 0 & 5 & 0 & 3 & 3 & 5 & 0 & 1 & 1 & 1 \\
\hline $\mathrm{L} / \mathrm{N}$ & 1.0 & $\mathrm{n} / \mathrm{a}$ & $\mathrm{n} / \mathrm{a}$ & 0.2 & $\mathrm{n} / \mathrm{a}$ & $\mathrm{n} / \mathrm{a}$ & 2.7 & $\mathrm{n} / \mathrm{a}$ & $\mathrm{n} / \mathrm{a}$ & 0.2 & $\mathrm{n} / \mathrm{a}$ & $\mathrm{n} / \mathrm{a}$ \\
\hline
\end{tabular}

Identified with aid of a light microscope.

L: larvae; N: nymph; F: female; M: male; U: unidentified; L/N ratio: larvae/nymph ratio; n/a: not applicable

control area, but unfortunately such areas were not available for this study. Therefore, nearby areas were chosen that did not suit as lizard habitats but also differed in vegetation type.

The current study confirms earlier observations ticks taken from lizards, including sand lizards, are almost free of B. burgdorferi s.l. $[16,20,21,29,63]$. B. burgdorferi lusitaniae which can be sustained in lizards, was not detected in this study [15]. Only very recently and in an unrelated study, we discovered B. burgdorferi lusitaniae in questing ticks in the Netherlands for the first time (not shown). This study indicates that sand lizards are probably incompetent hosts for B. burgdorferi species commonly present. To confirm the incompetence of sand lizards to acquire or transmit $B$. burgdorferi further studies and direct sampling of lizard tissue will be necessary.
We did not find evidence of a dilution effect of sand lizards since the B. burgdorferi prevalence in questing ticks collected from forest and heather vegetation were similar. How high the B. burgdorferi prevalence would be in the same habitat without lizards is unknown. Our data corroborate the previous notion that an incompetent host does not automatically act as a dilution host [26,28]. Studies on the effects of small rodent densities in combination with lizard densities (including the more abundant common lizard) in relation to B. burgdorferi infestation rate in questing and attached ticks would further deepen the knowledge on the specific characteristics of lizards as possible dilution hosts for $B$. burgdorferi. A high passive mobility of ticks would also lead to an attenuation of a dilution effect [64] that would be relatively high in small lizard habitats as studied here. An increased abundance

Table 4: Density of ticks in heather and forest.

\begin{tabular}{|c|c|c|c|c|c|c|c|c|}
\hline \multirow[t]{2}{*}{ Location } & \multicolumn{2}{|c|}{ Heumensoord } & \multicolumn{2}{|c|}{ Bergherbos } & \multicolumn{2}{|c|}{ Leusderheide } & \multicolumn{2}{|c|}{ Hullenberg } \\
\hline & Heather & Forest & Heather & Forest & Heather & Forest & Heather & Forest \\
\hline $\begin{array}{l}\text { Tick density } \\
{\left[100 \mathrm{~m}^{-2}\right]}\end{array}$ & 12.5 & 72.5 & 3.3 & 16.5 & 19.5 & 102 & 8.5 & 51.0 \\
\hline $95 \% \mathrm{Cl}$ & $10-15$ & $65-79$ & $1-6$ & $11-22$ & $15-24$ & $90-110$ & $5-12$ & $42-61$ \\
\hline $\begin{array}{l}\text { Lizard } \\
\text { density }\left[\mathrm{ha}^{-1}\right]\end{array}$ & $<50$ & 0 & 75 & 0 & 100 & 0 & 100 & 0 \\
\hline $\begin{array}{l}\text { Ticks per } \\
\text { lizard }\end{array}$ & $2.7(18)$ & & $2.4(25)$ & & $2.9(19)$ & & $1.9(30)$ & \\
\hline
\end{tabular}

Values are averages of 4 measurements and a 95\% confidence interval was calculated with bootstrap analysis with 5000 replications (QP 3.0). Lizard densities were estimated based on data of the national reptile monitoring network [56]. 
Table 5: Number of ticks calculated per sand-lizard, per age-, and sex group.

\begin{tabular}{lcccc}
\hline & $\mathbf{n}$ & range ticks/lizard & mean ticks/lizard & $\mathbf{9 5 \%} \mathbf{C l}$ \\
\hline Male & 51 & $1-11$ & 3.2 & $2.5-4.1$ \\
\hline Female & 39 & $0-16$ & 3.6 & $2.7-4.8$ \\
\hline Sub-adult & 2 & $1-2$ & 1.5 & n.c. \\
\hline Total & 92 & $0-16$ & 3.3 & $2.8-4.0$ \\
\hline
\end{tabular}

n.c.: not calculated.

Data are from all four study areas. Mean and confidence intervals were calculated with bootstrap analysis with 5000 replications (QP 3.0) [60].

of sand lizards might have effects on B. burgdorferi s.l., like a decrease of its overall prevalence in questing ticks, but also on the emergence of adapted species like B. burgdorferi lusitaniae and other tick-borne pathogens.

As found previously, $R$. helvetica was the most prevalent Rickettsia species found in The Netherlands [37]. $R$. helvetica is of uncertain pathogenicity but in recent years increasing numbers of publications confirm the pathogenic status of $R$. helvetica [42-49]. Scant evidence of $R$. typhi was found in three ticks. The DNA of $R$. typhi has been detected in tick lysates before, but its relevance is unclear [37]. Several isolates could not be identified to species level because their sequences did not match with sequences currently available at the NCBI database. Their closest matches were $R$. bellii.

High spatial variations of Rickettsia infection rates as found during this study had been observed in earlier studies at our laboratory and have also been reported by other groups [40]. Variations in Rickettsia prevalence at sites that are distant from each other can be due to a number of factors. Most rickettsial species can be transmitted transovarially and therefore their prevalence in a given tick population depends on the infection rate in the parent generation, the transovarial transmission rate and the presence of vertebrate reservoir hosts that can trans-

Table 6: Attachment sites of ticks.

\begin{tabular}{lccc}
\hline & left & right & total \\
\hline Flanks & 9 & 13 & 22 \\
\hline Armpit & 120 & 145 & 265 \\
\hline near eye & 1 & & 1 \\
\hline In/near tympanum & 1 & 0 & 2 \\
\hline
\end{tabular}

The number of ticks counted at the indicated sites is shown, all data is pooled for the four study sites. mit the bacteria horizontally to previously uninfected ticks [65]. Rickettsia can therefore be endemic to a tick population without the obligatory need of reservoir hosts. In agreement with this, we previously reported similar $R$. helvetica prevalences in larvae, nymphs and adult ticks during a longitudinal study and concluded that ticks are a major reservoir for $R$. helvetica in the Netherlands [37]. Contrary Silaghi et al. reported much lower infection rates in nymphs than in adult ticks which might indicate the necessity of reservoir hosts to sustain rickettsial infection of a tick population on a long term [40]. Probably the maintenance of an infected population relies on both transmission pathways. The significantly higher prevalence of Rickettsia in ticks collected from sand lizards than those of questing ticks (forest and heather combined) is an indication that this host species might be a reservoir host for $R$. helvetica. Blood and tissue samples of lizards could have delivered additional information on the ability of sand lizards to maintain and transmit rickettsial infection but obtaining these would have been invasive and was therefore not possible.

For Anaplasma species the opposite picture was observed than for Rickettsia. Prevalence of Anaplasma was significantly lower in ticks collected from lizards compared to those from forest and heather vegetation indicating that lizards might be incompetent hosts for these pathogens.

A dilution effect for Anaplasma was not observed in the ticks collected from heather. In order to assess health risks for humans we attempted to calculate the infectedtick-density. The density of infected ticks is an approximation of the exposure risk and is therefore of importance when evaluating infection risks. Tick densities and density of infected ticks in forests were much higher $(\mathrm{p}<$ 0.0001 ) than in the corresponding heather areas the risk of exposure to a tick bite is higher as well. So even though the presence of lizards in heathland did not lead to a dilution effect, the risk of contracting Lyme disease is much lower in heathlands. The same is true for $R$. helvetica. 


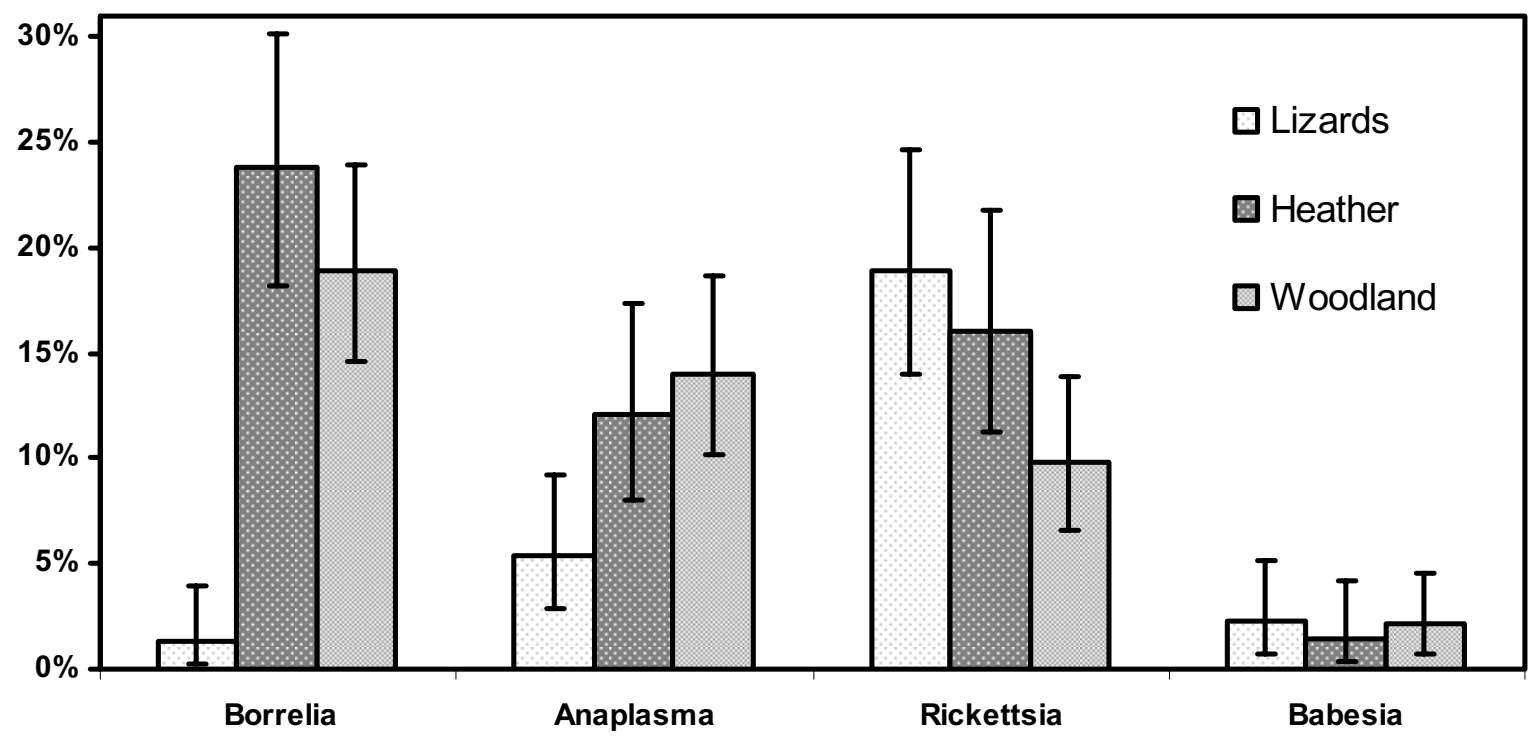

Figure 1 Infection rates for B. burgdorferi burgdorferi s.l., Anaplasma spp., Rickettsia spp. and Babesia spp. of ticks collected from lizards, heather or woodland vegetation. Four sampled areas were analyzed conjointly. Confidence intervals were calculated with Fisher's exact test [59]

Low tick density in heather had been reported previously $[66,67]$ and can at least partly be explained by the typically sandy, free-draining grounds that provide little protection for the ticks against desiccation.

The four areas were classified as having very high (Leusderheide and Hullenberg), high (Bergherbos) and medium (Heumensoord) lizard densities. Surprisingly, the lizard density seems to be positively associated with B. burgdorferi prevalence in ticks. However, as lizard density data are only rough estimates, the positive association could not be tested with statistical methods. This study has shown that a single vertebrate species correlates with different tick-borne pathogens in opposing directions. While sand lizards are probably incompetent hosts for the B. burgdorferi species present in the Netherlands they seem to be reservoir hosts for Rickettsia spp. The different impacts of any single vertebrate host on tick-borne diseases will make it difficult to reduce the overall tick-borne disease risks for man and pets by manipulating vertebrate host communities. Reduction of tick-densities is a more immediate measure to reduce exposure and would evenly decrease the risk of all tickborne diseases. A reduction of tick densities achieved by altering vegetation or reducing the abundance of vertebrate hosts for adult ticks is unpredictable and not ecologically acceptable. The low tick numbers in heather mean a decreased risk for Lyme disease or rickettsioses and with regard to tick-borne diseases heathland therefore seems a safer recreational area than woodland.

\section{Competing interests}

The authors declare that they have no competing interests.

\section{Authors' contributions}

ET and MF collected data, performed lab tests and developed new methodology. ET analyzed data and wrote initial draft. HS and JR designed the study and wrote the final manuscript. AS designed the study, collected data, provided data on lizard density, and co-refined the intellectual content of the manuscript.

\section{Acknowledgements}

This study was financially supported by the Dutch Food and Consumer Product Safety Authority (VWA), and by the Ministry of Health, Welfare and Sport. We thank F. Kuenen, W. van den Heuvel, A. van Rijsewijk and F. Tissen (RAVON) for collecting ticks. J. van der Giessen and M. Braks (LZO) are acknowledged for stimulating discussions and J. v. Delft (RAVON) for his comments on the manuscript. Capturing lizards and sample collection were carried out with official permission from the Dutch Ministry of Agriculture, Nature and Food Quality (FF/75A/2009/035)

\section{Author Details}

1 Laboratory for Zoonoses and Environmental Microbiology, National Institute for Public Health and Environment (RIVM), Antonie van Leeuwenhoeklaan 9, PO Box 1, Bilthoven, the Netherlands, ${ }^{2}$ Laboratory for Infectious Diseases and Screening, National Institute for Public Health and Environment (RIVM), Antonie van Leeuwenhoeklaan 9, PO Box 1, Bilthoven, the Netherlands and 3Reptile, Amphibian and Fish Conservation Netherlands (RAVON), PO Box 1413, 6501 BK Nijmegen, the Netherlands

Received: 15 March 2010 Accepted: 14 May 2010

Published: 14 May 2010

\section{References}

1. Hofhuis A, Giessen JW van der, Borgsteede FH, Wielinga PR, Notermans DW, van Pelt W: Lyme borreliosis in the Netherlands: strong increase in GP consultations and hospital admissions in past 10 years. Euro Surveill 2006, 11: E060622 060622

2. Smith R, Takkinen J: Lyme borreliosis: Europe-wide coordinated surveillance and action needed? Euro Surveill 2006, 11:. E060622 060621 
3. Parola P, Paddock CD, Raoult D: Tick-borne rickettsioses around the world: emerging diseases challenging old concepts. Clin Microbiol Rev 2005, 18:719-756

4. Parola P, Raoult D: Tick-borne bacterial diseases emerging in Europe. Clin Microbiol Infect 2001, 7:80-83.

5. Jones KE, Patel NG, Levy MA, Storeygard A, Balk D, Gittleman JL, Daszak P. Global trends in emerging infectious diseases. Nature 2008, 451:990-993.

6. Morens DM, Folkers GK, Fauci AS: The challenge of emerging and reemerging infectious diseases. Nature 2004, 430:242-249.

7. Smith GJ, Vijaykrishna D, Bahl J, Lycett SJ, Worobey M, Pybus OG, Ma SK, Cheung CL, Raghwani J, Bhatt S, Peiris JS, Guan Y, Rambaut A: Origins and evolutionary genomics of the 2009 swine-origin $\mathrm{H} 1 \mathrm{~N} 1$ influenza A epidemic. Nature 2009, 459:1122-1125.

8. Tabachnick WJ: Challenges in predicting climate and environmental effects on vector-borne disease episystems in a changing world. J Exp Biol 213:946-954.

9. Kurtenbach K, De Michelis S, Etti S, Schafer SM, Sewell HS, Brade V, Kraiczy $\mathrm{P}$ : Host association of Borrelia burgdorferi sensu lato--the key role of host complement. Trends Microbiol 2002, 10:74-79.

10. Kurtenbach K, Peacey M, Rijpkema SG, Hoodless AN, Nuttall PA, Randolph SE: Differential transmission of the genospecies of Borrelia burgdorferi sensu lato by game birds and small rodents in England. App/ Environ Microbiol 1998, 64:1169-1174.

11. Kurtenbach K, Sewell HS, Ogden NH, Randolph SE, Nuttall PA: Serum complement sensitivity as a key factor in Lyme disease ecology. Infect Immun 1998, 66:1248-1251.

12. Piesman J: Ecology of Borrelia burgdorferi sensu lato in North America. In Lyme borreliosis: biology, epidemiology, and control Edited by: Gray J, Kahl O, Lane RS, Stanek G. Wallingford, UK: CABI Pub; 2002.

13. Talleklint-Eisen L, Eisen RJ: Abundance of ticks (Acari: Ixodidae) infesting the western fence lizard, Sceloporus occidentalis, in relation to environmental factors. Exp Appl Acarol 1999, 23:731-740.

14. Scali S, Manfredi MT, Guidali F: Lacerta bilineata (Reptilia, Lacertidae) as a host of Ixodes ricinus (Acari, Ixodidae) in a protected area of northern Italy. Parassitologia 2001, 43:165-168.

15. Richter D, Matuschka FR: Perpetuation of the Lyme disease spirochete Borrelia lusitaniae by lizards. Appl Environ Microbiol 2006, 72:4627-4632.

16. Matuschka FR, Fischer P, Heiler M, Richter D, Spielman A: Capacity of European animals as reservoir hosts for the Lyme disease spirochete. $J$ Infect Dis 1992, 165:479-483.

17. Wright SA, Lane RS, Clover JR: Infestation of the southern alligator lizard (Squamata: Anguidae) by Ixodes pacificus (Acari: Ixodidae) and its susceptibility to Borrelia burgdorferi. J Med Entomol 1998, 35:1044-1049.

18. Dsouli N, Younsi-Kabachii H, Postic D, Nouira S, Gern L, Bouattour A: Reservoir role of lizard Psammodromus algirus in transmission cycle of Borrelia burgdorferi sensu lato (Spirochaetaceae) in Tunisia. J Med Entomol 2006, 43:737-742.

19. Majlathova V, Majlath I, Derdakova M, Vichova B, Pet'ko B: Borrelia lusitaniae and green lizards (Lacerta viridis), Karst Region, Slovakia. Emerg Infect Dis 2006, 12:1895-1901.

20. Foldvari G, Rigo K, Majlathova V, Majlath I, Farkas R, Pet'ko B: Detection of Borrelia burgdorferi sensu lato in lizards and their ticks from Hungary. Vector Borne Zoonotic Dis 2009, 9:331-336.

21. Lane RS, Mun J, Eisen L, Eisen RJ: Refractoriness of the western fence lizard (Sceloporus occidentalis) to the Lyme disease group spirochete Borrelia bissettii. J Parasitol 2006, 92:691-696.

22. Lane RS, Quistad GB: Borreliacidal factor in the blood of the western fence lizard (Sceloporus occidentalis). J Parasitol 1998, 84:29-34.

23. Kuo MM, Lane RS, Giclas PC: A comparative study of mammalian and reptilian alternative pathway of complement-mediated killing of the Lyme disease spirochete (Borrelia burgdorferi). J Parasitol 2000, 86:1223-1228

24. Ullmann AJ, Lane RS, Kurtenbach K, Miller M, Schriefer ME, Zeldner N, Piesman J: Bacteriolytic activity of selected vertebrate sera for Borrelia burgdorferi sensu stricto and Borrelia bissettii. J Parasitol 2003, 89:1256-1257

25. LoGiudice K, Duerr ST, Newhouse MJ, Schmidt KA, Killilea ME, Ostfeld RS: Impact of host community composition on Lyme disease risk. Ecology 2008, 89:2841-2849.
26. LoGiudice K, Ostfeld RS, Schmidt KA, Keesing F: The ecology of infectious disease: effects of host diversity and community composition on Lyme disease risk. Proc Natl Acad Sci USA 2003, 100:567-571.

27. Lane RS: Susceptibility of the western fence lizard (Sceloporus occidentalis) to the Lyme borreliosis spirochete (Borrelia burgdorferi). Am J Trop Med Hyg 1990, 42:75-82.

28. Keesing F, Holt RD, Ostfeld RS: Effects of species diversity on disease risk. Ecol Lett 2006, 9:485-498

29. Giery ST, Ostfeld RS: The role of lizards in the ecology of Lyme disease in two endemic zones of the northeastern United States. J Parasitol 2007, 93:511-517.

30. Casher L, Lane R, Barrett R, Eisen L: Relative importance of lizards and mammals as hosts for ixodid ticks in northern California. Exp Appl Acarol 2002, 26:127-143.

31. Cremer R, van Delft J: Ecologie en levenswijze. In De amfibieën en reptielen van Nederland Leiden: Stichting Uitgeverij KNNV; 2009:476. [Nederlandse fauna 9]

32. Strijbosch $\mathrm{H}$, Creemers RCM: Comparative demography of sympatric populations of Lacerta vivipara and Lacerta agilis. Oecologia 1988, 76:20-26

33. Bauwens D, Strijbosch $H$, Stumpel AHP: The lizards Lacerta agilis and L. vivipara as hosts to larvae and nymphs of the tick Ixodes ricinus. Ecography 1983, 6:32-40

34. van Leeuwen $\mathrm{BH}$, Hoef JCM van de: Onderzoek naar de oecologie en populatie-dynamica van de Zandhagedis (Lacerta agilis) in de duinen van Oostvoorne. Vrije Universiteit Amsterdam, RIN (Leersum), Lab Zoölogische Oecologie en Taxonomie (Utrecht), Biologisch Lab VU (Amsterdam); 1976.

35. Anonymous: Let op: Lyme-gevaar. Teken ook op hagedissen. Nieuwsbrief Meetnet Reptilen, Amsterdam 2002, 23:14.

36. Gassner F, Verbaarschot P, Smallegange RC, Spitzen J, Van Wieren SE, Takken W: Variations in Ixodes ricinus density and Borrelia infections associated with cattle introduced into a woodland in The Netherlands. Appl Environ Microbiol 2008, 74:7138-7144.

37. Sprong $\mathrm{H}$, Wielinga PR, Fonville $\mathrm{M}$, Reusken $\mathrm{C}$, Brandenburg AH, Borgsteede F, Gaasenbeek C, Giessen JW van der: Ixodes ricinus ticks are reservoir hosts for Rickettsia helvetica and potentially carry flea-borne Rickettsia species. Parasit Vectors 2009, 2:41.

38. van Overbeek L, Gassner F, Plas CL van der, Kastelein P, Nunes-da Rocha U, Takken W: Diversity of Ixodes ricinus tick-associated bacterial communities from different forests. FEMS Microbiol Ecol 2008, 66:72-84.

39. Azad AF, Beard CB: Rickettsial pathogens and their arthropod vectors. Emerg Infect Dis 1998, 4:179-186.

40. Silaghi C, Gilles J, Hohle M, Pradel I, Just FT, Fingerle V, Kuchenhoff H, Pfister K: Prevalence of spotted fever group rickettsiae in Ixodes ricinus (Acari: Ixodidae) in southern Germany. J Med Entomol 2008, 45:948-955.

41. Inokuma H, Seino N, Suzuki M, Kaji K, Takahashi H, Igota H, Inoue S: Detection of Rickettsia helvetica DNA from peripheral blood of Sika deer (Cervus nippon yesoensis) in Japan. J Wildl Dis 2008, 44:164-167.

42. Nielsen H, Fournier PE, Pedersen IS, Krarup H, Ejlertsen T, Raoult D: Serological and molecular evidence of Rickettsia helvetica in Denmark. Scand J Infect Dis 2004, 36:559-563.

43. Fournier PE, Allombert C, Supputamongkol Y, Caruso G, Brouqui P, Raoult D: Aneruptive fever associated with antibodies to Rickettsia helvetica in Europe and Thailand. J Clin Microbiol 2004, 42:816-818.

44. Nilsson K: Septicaemia with Rickettsia helvetica in a patient with acute febrile illness, rash and myasthenia. J Infect 2008, 58:79-82.

45. Nilsson K, Lindquist O, Pahlson C: Association of Rickettsia helvetica with chronic perimyocarditis in sudden cardiac death. Lancet 1999, 354:1169-1173.

46. Nilsson K, Liu A, Pahlson C, Lindquist O: Demonstration of intracellular microorganisms (Rickettsia spp., Chlamydia pneumoniae, Bartonella spp.) in pathological human aortic valves by PCR. J Infect 2005, 50:46-52.

47. Nilsson K, Pahlson C, Lukinius A, Eriksson L, Nilsson L, Lindquist O: Presence of Rickettsia helvetica in granulomatous tissue from patients with sarcoidosis. J Infect Dis 2002, 185:1128-1138.

48. Cinco M, Luzzati R, Mascioli M, Floris R, Brouqui P: Serological evidence of Rickettsia infections in forestry rangers in north-eastern Italy. Clin Microbiol Infect 2006, 12:493-495 
49. Fournier PE, Grunnenberger F, Jaulhac B, Gastinger G, Raoult D: Evidence of Rickettsia helvetica infection in humans, eastern France. Emerg Infect Dis 2000, 6:389-392.

50. Anderson BE, Dawson JE, Jones DC, Wilson KH: Ehrlichia chaffeensis, a new species associated with human ehrlichiosis. J Clin Microbiol 1991, 29:2838-2842.

51. Dumler JS, Choi KS, Garcia-Garcia JC, Barat NS, Scorpio DG, Garyu JW, Grab DJ, Bakken JS: Human granulocytic anaplasmosis and Anaplasma phagocytophilum. Emerg Infect Dis 2005, 11:1828-1834.

52. Wielinga PR, Gaasenbeek C, Fonville M, de Boer A, de Vries A, Dimmers W, Akkerhuis Op Jagers G, Schouls LM, Borgsteede F, Giessen JW van der: Longitudinal analysis of tick densities and Borrelia, Anaplasma, and Ehrlichia infections of Ixodes ricinus ticks in different habitat areas in The Netherlands. Appl Environ Microbiol 2006, 72:7594-7601.

53. Hunfeld KP, Hildebrandt A, Gray JS: Babesiosis: recent insights into an ancient disease. Int J Parasitol 2008, 38:1219-1237.

54. Froberg MK, Dannen D, Bakken JS: Babesiosis and HIV. Lancet 2004 363:704.

55. Wielinga PR, Fonville M, Sprong H, Gaasenbeek C, Borgsteede F, Giessen JW: Persistent Detection of Babesia EU1 and Babesia microti in Ixodes ricinus in The Netherlands During a 5-Year Surveillance: 2003-2007. Vector Borne Zoonotic Dis 2008 in press.

56. Smit GFJ, Zuiderwijk A: Handleiding voor Monitoring van Reptielen in Nederland 3rd edition. Amsterdam: RAVON Werkgroep Monitoring; 2003.

57. Schouls LM, Pol I Van De, Rijpkema SG, Schot CS: Detection and identification of Ehrlichia, Borrelia burgdorferi sensu lato, and Bartonella species in Dutch Ixodes ricinus ticks. J Clin Microbiol 1999, 37:2215-2222

58. Christova I, Pol J Van De, Yazar S, Velo E, Schouls L: Identification of Borrelia burgdorferi sensu lato, Anaplasma and Ehrlichia species, and spotted fever group Rickettsiae in ticks from Southeastern Europe. Eur J Clin Microbiol Infect Dis 2003, 22:535-542.

59. Dean A, Sullivan K, Soe M: Open Source Epidemiologic Statistics for Public Health. 2.3th edition. 2009.

60. Reiczigel , Rózsa : Quantitative Parasitology. Budapest 3.0th edition. 2005

61. Brunner JL, LoGiudice K, Ostfeld RS: Estimating reservoir competence of Borrelia burgdorferi hosts: prevalence and infectivity, sensitivity, and specificity. JMed Entomol 2008, 45:139-147.

62. Gryczyńska-Siemiątkowska A, Siedlecka A, Stanńczak J, Barkowska M: Infestation of sand lizards (Lacerta agilis) resident in the Northeastern Poland by Ixodes ricinus (L.) ticks and their infection with Borrelia burgdorferi sensu lato. Acta Parasitologica 2007, 52:165-170.

63. Majláthová V, Majláth I, Hromada M, Tryjanowski P, Bona M, Antczak M, Víchová B, Dzimko S, Mihalca A, Petko B: The role of the sand lizard (Lacerta agilis) in the transmission cycle of Borrelia burgdorferi sensu lato. International Journal of Medical Microbiology 2008, 298:161-167.

64. Crooks E, Randolph SE: Walking by Ixodes ricinus ticks: intrinsic and extrinsic factors determine the attraction of moisture or host odour. $J$ Exp Biol 2006, 209:2138-2142.

65. Raoult D, Roux V: Rickettsioses as paradigms of new or emerging infectious diseases. J Clin Microbiol Rev 1997, 10:694-719.

66. Lindstrom A, Jaenson TG: Distribution of the common tick, Ixodes ricinus (Acari: Ixodidae), in different vegetation types in southern Sweden. J Med Entomol 2003, 40:375-378.

67. Estrada-Pena A: Distribution, abundance, and habitat preferences of Ixodes ricinus (Acari: Ixodidae) in northern Spain. J Med Entomol 2001 38:361-370

68. Rijpkema SG, Molkenboer MJ, Schouls LM, Jongejan F, Schellekens JF: Simultaneous detection and genotyping of three genomic groups of Borrelia burgdorferi sensu lato in Dutch Ixodes ricinus ticks by characterization of the amplified intergenic spacer region between $5 \mathrm{~S}$ and 23 S rRNA genes. J Clin Microbiol 1995, 33:3091-3095.

69. Alekseev AN, Dubinina HV, Pol I Van De, Schouls LM: Identification of Ehrlichia spp. and Borrelia burgdorferi in Ixodes ticks in the Baltic regions of Russia. J Clin Microbiol 2001, 39:2237-2242.

70. Bergmans AM, Groothedde JW, Schellekens JF, van Embden JD, Ossewaarde JM, Schouls LM: Etiology of cat scratch disease: comparison of polymerase chain reaction detection of Bartonella (formerly Rochalimaea) and Afipia felis DNA with serology and skin tests. J Infect Dis 1995, 171:916-923.
71. Gubbels JM, de Vos AP, Weide M van der, Viseras J, Schouls LM, de Vries E, Jongejan F: Simultaneous detection of bovine Theileria and Babesia species by reverse line blot hybridization. J Clin Microbio/ 1999, 37:1782-1789.

doi: 10.1186/1756-3305-3-42

Cite this article as: Tijsse-Klasen et al., Role of sand lizards in the ecology of Lyme and other tick-borne diseases in the Netherlands Parasites \& Vectors 2010, 3:42

\section{Submit your next manuscript to BioMed Central} and take full advantage of:

- Convenient online submission

- Thorough peer review

- No space constraints or color figure charges

- Immediate publication on acceptance

- Inclusion in PubMed, CAS, Scopus and Google Scholar

- Research which is freely available for redistribution 